\title{
Müzik Eğitimi Ana Bilim Dalı Birinci Sınıf Öğrencilerinin Okul Çalgıları - Blok Flüt Dersinden Beklentileri: Uludağ Üniversitesi Örneği
}

\section{Ajda ŞENOL SAKİN*}

Öz: Blok flüt Türkiye'de 1960’lı yıllardan günümüze kullanılan genel müzik eğitimi çalgısıdır. Müzik Eğitimi Ana Bilim Dalı programlarında Okul Çalgıları - Blok Flüt dersi ile amaçlanan, müzik öğretmeni adayı olan öğrencilerin bu çalgıya yönelik çalma becerilerinin yanı sıra öğretme becerilerinin de geliştirilmesidir. Araştırma aksiyon araştırmasıdır. Araştırmada, öğrencilerin Okul Çalgıları - Blok Flüt dersinden beklentilerini belirleyebilmek için görüşmeler yapılmıştır. 2016-2017 Güz döneminde Okul Çalgıları - Blok Flüt dersini seçen on beş öğrenci ile görüşülmüş ve onların bu dersten müzikal beklentileri, müzik öğretmenliği açısından beklentileri, Türk Müziği açısından beklentileri ve genel beklentileri ortaya konulmuştur. Araştırma sonucunda öğretmenlik mesleği açısından öğrencilerin beklentileri iyi çalma ve iyi ögrretme olarak kodlanmıştır. Araştırmaya katılan öğrenciler, daha önce genel müzik eğitimlerinde blok flüt eğitimi almış olmalarına rağmen Okul Çalgıları Blok Flüt dersinin gerekli olduğunu belirtmişlerdir. Öğrenciler, blok flütün diğer çalgılar ile kıyaslandığında daha ucuz ve öğrenilmesi daha kolay bir çalgı olduğu için genel müzik eğitimi açısından uygun bir çalg1 olduğunu, bu çalg1 ile çoksesli müzik algısının arttırılabileceğini belirtmişlerdir. Ayrıca, öğretebilecek düzeyde çalabilmek, deşifre kabiliyetlerini arttırmak öğrencilerin bu dersten beklentileri arasındadır. Araştırma sonucunda öğrencilerin bu derse yönelik önerilerine yer verilmiştir.

Anahtar Kelimeler: Blok flüt, müzik eğitimi, öğrenci beklentileri.

\footnotetext{
* Uludağ Üniversitesi, Eğitim Fakültesi, GSE Bölümü Müzik Eğitimi Ana Bilim Dalı, ajdasenol@gmail.com, Görükle/Bursa.

\begin{tabular}{lll}
\hline Gönderim:03.12.2016 & Kabul:22.02.2017 & Yayın:03.04.2017 \\
\hline
\end{tabular}
}




\title{
Music Education Department First Class Students Expectations for School Instruments - Recorder Course: An Example of Uludag University
}

\begin{abstract}
Recorder is a general music education instrument that is used from 1960's to present in Turkey. It is aimed development of teaching skills as well as playing skills for the students who are candidates for music teaching with the School Instruments Recorder course in department of music education. Research is an action research. In the study, interviews were held to determine the expectations of the students from the School Instruments - Recorder course. Fifteen students were interviewed who choose School Instruments - Recorder course during Fall Semester 2016-2017 and their expectations are revealed in terms of musical, teaching proggession, Turkish Music and general. As a result of research, students' expectation from School Instruments Recorder in terms of teaching profession was coded as a well play and well teach. Although the students have learned to play recorder in their general music education they found the School Instruments - Recorder course necessary. Students think that recorder is suitable for general music education because of cheap and easy to learn compare with other instruments. Also students say that polyphonic musicality can be increased with recorder. Students generally expect from the School Instruments Recorder course to steal well in the level where the instrument can be taught, to strengthen the sight-read and increase the skills. As a result of the research, the students' suggestions about this course are given.
\end{abstract}

Keywords: Recorder, music education, studets expectations. 


\section{Giriş}

Blok flüt, müzik eğitiminin temelini oluşturabilecek çalgı çalma eğitimi, müziksel yaratma eğitimi, müziksel bilgilenme eğitimi, müziksel beceri geliştirme eğitimi, müzikten yararlanma eğitimine (Uçan'dan aktaran Bozkaya, 2001) katkı sağlayan ve sadece Türkiye'de değil dünyanın pek çok ülkesinde kullanılan genel müzik eğitimi çalgısıdır. Örneğin Caroll yayımladığı makalesinde Avustralya'da blok flütün müzik eğitimi müfredatına 1940’lı y1llarda girdiğini (Caroll, 1968), Chaseling ve Boyd (2014)'da blok flütün New South Wales eyaletindeki okulların müzik müfredatına 1941 yılında eklendiğini belirtmişlerdir. Blok flütün Türkiye'de eğitim müziğine girmesinde, 1953 yılında Ankara'ya gelen Prof. Hermann Auer'in müzik öğretmenleri için düzenlediği kurslar etkili olmuştur. Genel müzik eğitimi içerisinde blok flütün yaygınlaşması, 1960'larda Saadettin Ünal'ın başlattığı uygulamalarla ve metotlarının yayımlanmasıyla olmuştur (Say, 2010; Önal ve Aydoğan, 2012, Kıvrak, 2003). Blok flüt 1971 yılında Müzik Taslak Programında ve sonrasında hazırlanan müzik programlarında yer almıştır (Kocabaş, 1995).

Ünal (1987), blok flütün eğiticiliği, kolaylığı ve gerçek bir sanat çalgısı olması nedeniyle okul çalgısı olarak müzik programlarında yer alması gerektiğini vurgulamaktadır. “Blok flüt eğitimi ile çocuklarımızın evrensel bir dil sayılan müzik dilini öğreneceklerini ve bu büyüleyici dil ile kendilerini ifade etme olanağına kavuşacaklarını” belirtmektedir (Ünal, 1987). 
Bazı araştırmalarda ise blok flütün müzik eğitiminde kısmen yeterli bir çalgı olduğu sonuçları yer almaktadır (Önal ve Aydoğan, 2012; Öcal, 2014). Araştırmalar incelendiğinde bu yetersizliğin nedenlerinin genelde ders programlarında yer alan hedeflerin blok flüt eğitimine yönelik hazırlanmadığı ve repertuvarın yetersiz olduğu sonucuna varılmış, aksaklıkların giderilmesine yönelik öneriler getirilmiştir (Önal ve Aydoğan, 2012; Öcal, 2014).

Müzik öğretmenliği programlarında, öğrenciler geleneksel ve orkestra çalgılarının yanı sıra okul çalgıları eğitimi de almaktadırlar (Bozkaya, 2001). Müzik eğitimi ana bilim dalı programlarında Okul Çalgıları dersleri blok flüt, gitar ve bağlama çalgılarını kapsayacak şekilde tek bir ders adı altında ve zorunlu olarak yer almaktadır. Bazı bölümlerde bu ders bölünerek seçmeli ders olmuş ve Okul Çalgıları - Gitar, Okul Çalgıları - Blok Flüt, Okul Çalgıları - Mandolin, Okul Çalgıları - Orff Çalgıları ve Okul Çalgıları - Vurmalı Çalgılar ya da Okul Çalgıları - 1, Okul Çalgıları - 2 olarak adlandırılmıştır.

Yükseköğretim Kurulunun (YÖK) 2006-2007 eğitim öğretim yılında hazırladığ1 Müzik Öğretmenliği Lisans Programında “Okul Çalgıları” Blok Flüt dersinin ders içeriği "Çalgının özellikleri, yapılışı ve aile içindeki konumu, ses alanı ve olanakları. Okul müzik eğitiminde kullanılma nedenleri, tutuş, üfleme ve ses üretme teknikleri. Küçük ölçekli ezgileri çalma, şarkı, türkü, marş ve çeşitli eğitim müziklerinde uygulamalı çalışmalar” olarak tanımlanmaktadır (Müzik Öğretmenliği Lisans Programı, 2016).

Bazı müzik eğitimi ana bilim dallarında dersin amacı;

- $\mathrm{Bu}$ ders ile blok flütün okul müzik eğitiminde kullanılmasına yönelik bilgi ve becerilerin kazandırılması amaçlanmaktadır (Abant İzzet Baysal Üniversitesi, 2016),

- Okul çalgılarının müzik eğitimindeki yeri ve önemini kavrama. Sınıf çalgısı olabilecek olan bu çalgılara öğrencilerin yetkin bir biçimde çalmalarını sağlamak ve mezun 
olduklarında bu çalgıyı rahatça öğretebilecek düzeye getirme ve okul çalgı toplulukları oluşturabilecek dağarcığı kazanma (Dokuz Eylül Üniversitesi, 2016),

- Sınıf çalgısı olabilecek olan bu çalgıları öğrencilerin yetkin bir biçimde çalmalarını sağlamak ve mezun olduklarında bu çalgıyı rahatça öğretebilecek düzeye getirmek ve okul çalgı toplulukları oluşturabilecek dağarcığı kazandırmak (Marmara Üniversitesi, 2016),

- Bu ders, Okul çalgılarının (Blok flüt) müzik eğitiminde nasıl kullanılacağını, çalgıların teknik özelliklerini, okul müziği dağarcığındaki yerini ve uygulamalarını kapsar. Ayrıca müzik öğretiminin gereği olan sanatsal anlayışın oluşturulması ve çalgı eğitimiyle müzik eğitimindeki gerekli çalışma disiplininin kavranmasını amaçlar (Uludağ Üniversitesi Ders Öğretim Planı, 2012) şeklinde belirtilmiştir.

Uludağ Üniversitesi Müzik Eğitimi Ana Bilim Dalında Okul Çalgıları - Blok Flüt dersinde yapılan uygulamalar, öğrencilerin öğretmenlik sürecine yardımcı olması amacı ile blok flüt çalmayı öğrenmenin yanı sıra nasıl öğretileceğine yönelik de hazırlanmaktadır. Doğru duruş, tutuş ve üfleme şekilleri öğretildikten sonra notalar sırasıyla öğretilirken öğrenilen bilgilerin pekiştirilmesi amacıyla ulusal ve uluslararası ezgilerden tek sesli ve çift sesli olarak yararlanılmaktadır.

Uludağ Üniversitesi Müzik Eğitimi Ana Bilim Dalında blok flüt eğitiminde kullanılan Türk metotlar, Prof. Saadettin Ünal'ın ve Salih Aydoğan/Aydın İlik'in blok flüt metotlarıdır.

Prof. Sadettin Ünal - Blokfülüt*Çalıyorum 1-2 (1987) metodunda açıklamalar Türkçe ve İngilizce olarak yapılmıştır. Tutuş hakkında bilgi verildikten sonra si notasından başlanmış ve notalar inici olarak öğretilmiştir. Öncelikle dörtlük, ikilik ve birlik nota değerleri öğretilmiş sonrasında sekizlik, noktalı dörtlük ve onaltılık nota değerlerine geçilmiştir. Metotta

\footnotetext{
${ }^{*}$ Bahsedilen metot isimleri orijinallerine sadık kalınarak yazılmıştır.
} 
alıştırmaların yanı sıra özgün parçalara, Türk Halk Müziği türkülerine, ulusal ve uluslararası çocuk şarkılarına, ünlü bestecilerin eserlerinden ezgilere tek sesli ve çift sesli olarak yer verilmiştir. Parçalar farklı ölçü sayılarında olup aksak ölçüler de kullanılmıştır. Yazarın 2. Metodu devam niteliğinde olup teknik çalışmalar, ezgi aktarma (transpoze) çalışmaları, çift dil vurma, tril ve süslemeler gibi konular içermektedir.

Salih Aydoğan/A. Aydın İlik - Blokflüt ile Müzik Eğitimi (2016) metodunda ise blok flüt ile çalgı eğitimi yapılmasının yanı sıra yer alan "ezgi tamamlama alıştırmaları, tartımları bir misli büyütmeli küçültmeli ezgiler, doğaçlama alıştırmaları, ezgi aktarmaları, hız ve gürlük işaretleri koyma, değiştirici işaretlerin yerini bulma, söz kalıplarıyla çalışma” gibi uygulamalarla yaratıcılık eğitimi, ses eğitimi uygulamaları, müziksel işitme eğitimi uygulamaları ve dağarcık kazanma uygulamaları ile çok amaçlı bir metot hazırlamışlardır. Metotta blok flütün kısa tarihi, yapısal özellikleri, kullanımı, ses tablosu bilgilerine yer verilmiş ve sol sesinden öğretime başlanmıştır. Öğrenilen notalar, tekerlemeler, özgün parçalar, şarkılar, türküler ve tanınmış bestecilerin ezgileri ile tek sesli, çift sesli, üç sesli ve farklı vurmalı çalgılar eşliğinde düzenlenerek tekrar edilmiştir.

İçerikleri ayrıntılı olarak açıklanan metotların yanı sıra dağarcık geliştirmek adına kullanılabilecek bazı Türk blok flüt metotları şöyledir:

- Saip Egüz - Türkü ve Oyun Havalarımızdan Bir Demet*

- Turabi Değerli - Blok Flüt Metodu ${ }^{\dagger}$

- Temel Hakkı Karahasan - Blokflüt Metodu

- Selçuk Yıldırım/Besim Akkuş - Halk Ezgileriyle Blokfülüt Metodu Okul Türkü Dağarcığg 1-2 (1987)

\footnotetext{
* Kitapta basım yılı bulunmamaktadır.

+ Kitapta basım yılı bulunmamaktadır.

${ }^{\ddagger}$ Kitapta basım yılı bulunmamaktadır.
} 
- İsmet Arıc1 - Sihirli Flüt Blok flüt Metodu (2007)

- Duygu Turan - Blokflüt Çalmaya Başlıyorum (2010)

- Salih Aydoğan - Renklerle Blokflüt Öğreniyorum (2011)

- Nedim Çalım - Blokflüt Öğreniyorum Blokflüt Metodu (2013)

Çağdaş ve günümüz koşullarına uygun öğretmenler yetiştirebilmek için, müzik eğitimi programları ve ders içerikleri sürekli olarak yenilenmeli, yaşanan sorunlara ve eksikliklere çözüm getirmek için araştırmalar yapılmalıdır. Dersler ile ilgili sorunların çözümünde “özellikle program geliştirme sürecinde öğrencilerin beklentilerinin bilinmesi ve bunlardan yararlanılması son derece önem taşımaktadır” (Öztürk, 2004). Öğrenci beklentileri dikkate alınmadığında "öğrenci beklentileri ve öğretim elemanının onlardan beklentisi arasındaki boşluk büyüyeceğinden dersin etkisi azalacaktır” (Redish, Saul ve Steinberg, 1998).

Müzik eğitimi ve öğretmenlik eğitimi alanlarında öğrenci beklentilerini ya da görüşlerini belirlemek için araştırmalar yapılmıştır. Yapılan araştırmalarda; Hamzaoğlu Birer (2016) yaptığı araştırmada öğrencilerin Okul Çalgıları I ve Okul Çalgıları II dersinden beklentileri ile bu beklentilerin karşılanma düzeyini belirlemiştir. Uçaner ve Şentürk (2013) müzik eğitimi ana bilim dalı öğrencilerinin Türk Müzik Tarihi dersinin işlenişine yönelik görüşlerini belirlemiş ve araştırmanın sonucunda öğrencilerin tutumlarını olumlu ve olumsuz etkileyen faktörleri belirleyerek öneriler getirilmiştir. Öztürk (2004) yaptığ1 araştırmada şan öğrencilerinin ses eğitiminden beklentilerini belirlemek amacıyla anket uygulaması yapmış ve öğrencilerin şan dersinden beklentilerinin "daha çeşitli ve işlevsel içeriklerin saptanması, İtalyanca eserlerin yanı sıra çağdaş Türk müziği örneklerinden de yararlanılması, etkili öğretim yöntemlerinin kullanılması, vb.” olduğu sonucuna varmıştır. Çelikkaya (2011) ise araştırmasında sosyal bilgiler öğretmen adaylarının öğretmenlik uygulaması dersinden beklentilerini ve bu beklentilerin karşılanma düzeylerini araştırarak “Öğretmenlik 
Uygulaması” dersinin verimli geçmesini amaçlamaktadır. Uluslararası düzeyde yapılmış öğrenci beklentileri ile ilgili çalışmalara, Brinkworth, McCann, Matthews ve Nordström'ün 2009 yılında yayımladıkları araştırmada, liseden mezun olan öğrencilerin üniversiteye adaptasyon sürecinde yaşadıkları zorlukları ve beklentilerini öğrenci/öğretmen perspektifinden incelemişlerdir. Crips ve çalışma arkadaşlarının (2009) birlikte yürüttükleri 1. Sınıf öğrenci görüşlerini içeren çalışma ile Appleton-Knapp ve Krentler'in (2006) öğrenci beklentileri ve memnuniyetleri üzerine yaptıkları çalışma örnek olarak gösterilebilir.

\section{Araştırmanın Amacı}

Genel müzik eğitiminde uzun yıllardır yer alan blok flüt eğitimine yönelik öğrenci beklentilerini belirlemek, dersin daha işlevsel olarak işlenmesi açısından çok önemlidir. Çünkü Okul Çalgıları - Blok Flüt dersini alan öğrencilerin büyük çoğunluğu üniversite eğitimlerinden önce de blok flüt eğitimi almışlardır. $\mathrm{Bu}$ nedenle, dersin içeriğinin ve işlenişinin öğrenci görüşleri doğrultusunda belirlenip, çalgının nasıl öğretileceğine yönelik uygulanması gerektiği düşünülmektedir.

Çalışmanın amacı öğrencilerin Okul Çalgıları - Blok Flüt dersinden beklentilerini belirlemektir.

Bu amaca yönelik çalışmanın problem cümlesi "Uludağ Üniversitesi Müzik Eğitimi Ana Bilim Dalı 1. Sınıf öğrencilerinin Okul Çalgıları - Blok Flüt dersine yönelik beklentileri nelerdir?" olarak belirlenmiştir.

Çalışmanın problemini çözümlemek adına belirlenen alt problemler şöyledir:

Öğrencilerin Okul Çalgıları - Blok Flüt dersinden;

- Müzikal gelişimleri açısından beklentileri nelerdir? 
- Müzik öğretmenliği mesleği açısından beklentileri nelerdir?

- Türk Müziği açısından beklentileri nelerdir?

- Okul Çalgıları - Blok Flüt dersine yönelik önerileri nelerdir?

\section{Yöntem}

Araştırma deseni. Araştırma eylem araştırmasıdır. Araştırma ile "öğretmen adaylarının ve mevcut öğretmenlerin kendi uygulamalarının doğası hakkında daha derinlemesine bir görüş ve anlayış kazanmaları amaçlanmaktadır” (Çepni, 2014). Eylem araştırmasının aşamaları "Tanılama, Tanımlama, Geliştirme, Uygulama ve Değerlendirme” şeklinde yapılandırılabilir (Büyüköztürk ve diğ., 2014).

$\mathrm{Bu}$ aşamalara göre araştırmanın tanılama aşaması öğretmenin Okul Çalgıları - Blok Flüt dersini öğrenci beklentileri doğrultusunda geliştirmek istemesi fakat öğrenci beklentilerini bilmiyor oluşudur. Tanımlama aşamasında araştırmanın problem cümlesi “Uludağ Üniversitesi Müzik Eğitimi Ana Bilim Dalı 1. Sınıf öğrencilerinin Okul Çalgıları Blok Flüt dersine yönelik beklentileri nelerdir?” olarak belirlenmiştir. Geliştirme aşamasında öğrenci beklentilerini çok yönlü belirleyebilmek adına görüşme soruları hazırlanmış, uygulama ve değerlendirme aşamasında öğrencilerden görüşme sorularına yazılı olarak cevap vermeleri istenmiştir. 2016-2017 Güz döneminde gerçekleştirilen uygulama sonrasında öğrencilerin cevapları değerlendirilmiş, Bahar dönemi ders içeriği bu değerlendirme göz önünde bulundurularak hazırlanmıştır.

Çalışma grubu. Araştırmanın çalışma grubu, Uludağ Üniversitesi Müzik Eğitimi Ana Bilim Dalı 2016-2017 Güz döneminde Okul Çalgıları - Blok Flüt dersini alan sekiz erkek, yedi kız (n=15) öğrenci ile oluşturulmuştur. 2016-2017 Güz döneminde Okul Çalgıları - Blok flüt dersini alan 20 öğrenci bulunmaktadır. Çalışma tamamıyla gönüllülük esasına dayandığından görüşme sorularını yanıtlamak istemeyen 5 öğrenci uygulamaya katılmamıştır. 
Uygulamaya katılan öğrencilerin 14’ü 1. Sınıf öğrencisi ve Okul Çalgıları - Blok Flüt dersinin ilk defa almakta, bir öğrenci de 2. Sınıf öğrenci ve Okul Çalgıları - Blok flüt dersinin geçen sene başarısız olduğu için ikinci defa almaktadır.

Veri toplama araçları. Araştırmada öğrencilerin Okul Çalgıları - Blok Flüt dersinden beklentilerini belirleyebilmek amacıyla görüşme yapılmıştır. "Görüşme-mülakat, araştırma amacına uygun olarak hazırlanan soruların, görüşüne ihtiyaç duyulan kişiye/kişilere araştırmacı tarafından sorularak cevap alınması sürecidir” (Ural ve Kılıç, 2013). Görüşme soruları öğrencilere yazılı olarak verilmiş, öğrencilerin görüşlerini rahatlıkla dile getirebilmeleri için özellikle isim yazmamaları istenmiştir. Görüşme soruları hazırlanırken çeşitliliğin sağlanması amacıyla açık uçlu ve kapalı uçlu sorular hazırlanmış böylece açık uçlu sorular nitel veri çözümleme yöntemleri ile kapalı uçlu sorular nicel veri çözümleme yöntemleri (frekans olarak) ile çözümlenmiştir. Veri toplama aracı geliştirilirken, benzer içerikteki formlar incelenmiş, konu için gerekli sorular belirlenmiş ayrıca son soru olarak öğrencilere bu konu hakkındaki diğer görüşleri sorulmuştur.

Veri toplama süreci. Araştırma için geliştirilen görüşme soruları bilgisayar ortamında hazırlandıktan sonra Uludağ Üniversitesi Etik Kurulundan uygulama için izin alınmıştır. Uygulama öncesi araştırma konusu ve amacı öğrencilere ayrıntılı olarak açıklanmış, elde edilecek verilerin ders içeriğinin geliştirilmesi amacıyla kullanılacağı ayrıca sonuçların makale olarak yayımlanacağı belirtilmiştir. Yazılı olarak sorulan görüşme sorularının süre kısıtlaması yaşanmaması amacıyla ders sonrasında yanıtlanması ve bir sonraki hafta teslim edilmesi istenmiştir.

Verilerin analizi. Araştırmada yapılandırılmış kapalı uçlu sorulardan elde edilen veriler nicel veri çözümleme yöntemi olan frekans yöntemi ile çözümlenmiştir. Açık uçlu sorulardan elde edilen veriler betimsel analiz ve içerik analizi yöntemi ile çözümlenmiştir. 
http://dx.doi.org/10.23891/efdyyu.2017.15

ISSN:1305-020

Öğrencilerin Okul Çalgıları - Blok flüt dersinin gerekliliği hakkındaki yanıtları müzik ögretmenliği açısından gerekliliği, ögrenciler açısından gerekliliği ve çalgının kolay ulaşılabilir ve öğrenilebilir açısından gerekliliği olarak kodlanmıştır. Öğrencilerin Okul Çalgıları - Blok Flüt dersinden beklentileri müzikal gelişimleri, ögretmenlik mesleği ve Türk Müziği kategorilerine ayrılmıştır. Ayrıca Öğretmenlik mesleği kategorisinde iyi çalma ve iyi ögretme kodları belirlenmiştir.

\section{Bulgular}

\section{Öğrencilerin Blok Flüt Dersine Yönelik Görüşleri}

Öğrenciler ile yapılan görüşmelerde blok flüt dersine yönelik görüşlerini belirlemek için sorular sorulmuştur. "Müzik öğretmeni adayı olarak Okul Çalgıları - Blok Flüt dersini gerekli buluyor musunuz?" sorusuna 14 öğrenci evet, bir öğrenci hayır cevabını vermiştir (Şekil 1).

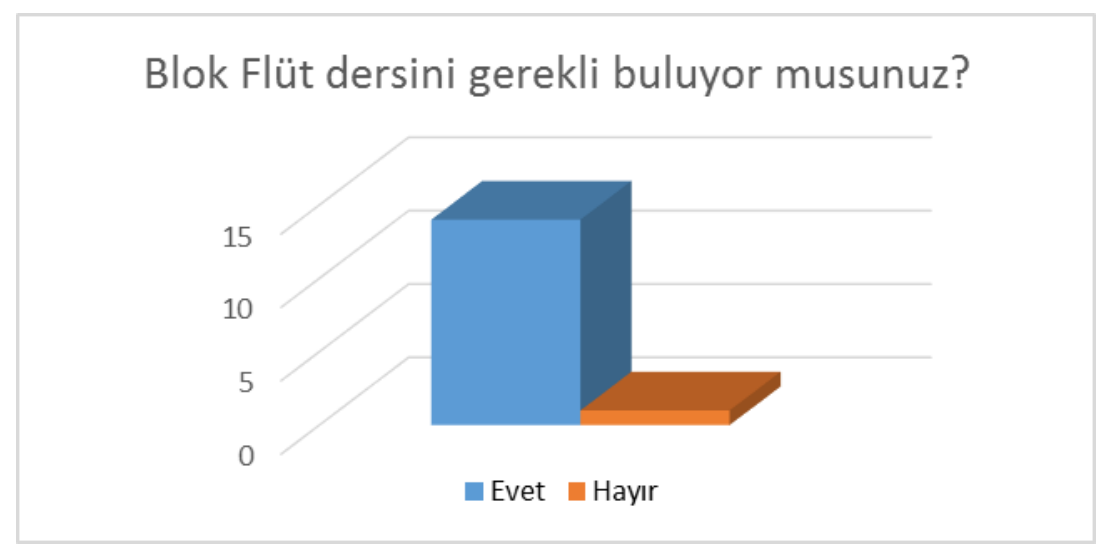

Şekil 1. Öğrencilerin Okul Çalgıları - Blok Flüt dersini gerekli bulma durumları

$\mathrm{Bu}$ soruya hayır diyen öğrenci açıklamada bulunmamış, bir öğrenci ”önceden flüt dersini gereksiz bulurdum ama ders almaya başladığımdan beri hoşuma gitmeye başladı ve keyif almaya başladım. Şimdi gerekli olduğunu düşünüyorum” şeklinde olumsuz olan düşüncesinin nasıl olumlu olarak değiştiğini açıklamıştır. 
Ayrıca öğrenciler bu soruya neden evet dediklerini açıklarken blok flüt eğitiminin gerekliliğini “müzik öğretmenliği”, “öğrenciler” ve “çalgının kolay ulaş1labilir ve öğrenilebilir” olması açısından değerlendirmişlerdir. Bu soruya açıklama yapmayarak sadece evet diyen öğrenci sayısı beştir. Bir öğrenci soruyu hem öğrenciler hem de çalgının kolay ulaşılabilir ve öğrenilebilir olması açısından değerlendirmiştir.

Okul Çalgıları - Blok Flüt dersinin gerekliliğinin müzik öğretmenliği açısından değerlendirilmesi. Üç öğrenci blok flüt dersinin gerekliliğini belirtirken "bu ders ile çocuklara blok flütü nasıl öğreteceğimizi öğreniyoruz” (Ö3), "birer müzik öğretmeni adayı olarak küçük çocuklara blok flütü daha sağlıklı ve doğru bir şekilde öğretebilmemiz için bu dersi gerekli buluyorum" (Ö5) ve "genel müzik eğitiminde blok flüt öğretildiği için bizim de bu çalgının eğitimini almamız ve her açıdan donanımlı olmamız gerekiyor" (Ö8) açıklamalarında bulunmuşlardır.

Okul Çalgıları - Blok Flüt dersinin gerekliliğinin öğrenciler açısından değerlendirilmesi. Blok flüt dersinin müzik eğitimi ana bilim dallarındaki gerekliliğini öğrenciler açısından değerlendiren üç öğrenci “çocukların müzikle tanışması ve kulak gelişimi açısından gerekli buluyorum” (Ö1), “çocukların müzik eğitiminde önemli bir çalgı” (Ö6) ve "blok flütün çocukları çalgı çaldırarak müziğin içine taşıdığını ve topluluk içinde var olabilme, özgüven sahibi olma ve notasına uygun, kurallara uygun bir şeyler icra edebilme, grup çalışması yapabilme ve çalışma disiplini kazandırma gibi pek çok müzikal davranışı pekiştirdiğini düşünüyorum" (Ö13) demiştir.

Okul Çalgıları - Blok Flüt dersinin gerekliliğinin çalgının kolay ulaşılabilir ve öğrenilebilir olması açısından değerlendirilmesi. Blok flütü kolay ulaşılabilir ve öğrenilebilir olması açısından değerlendiren üç öğrenci şu açıklamalarda bulunmuştur: “okullarda kullanılabilir ve ulaşılabilirlik açısından en rahat çalgı olduğunu düşünüyorum” 
(Ö9), “diğer çalgıların fiyatları daha pahalıyken blok flüte 20 TL'ye sahip olunabiliyor" (Ö11), "blok flüt Orff çalgılarından biri olduğu ve birçok çalgıya göre çalması daha kolay olduğu için gerekli olduğunu düşünüyorum" (Ö13).

Uludağ Üniversitesi Müzik Eğitimi Ana Bilim Dalında Okul Çalgıları - Blok Flüt dersi ilk yıl verilmektedir. Öğrencilere “Okul Çalgıları - Blok Flüt dersinin müzik öğretmenliği programında 1. yılda yer alıyor olması sizce uygun mu?” diye sorulduğunda 10 öğrenci evet, üç öğrenci hayır, bir öğrenci fark etmez ve bir öğrenci de "bence hiçbir dönem olmamalı. Aldığımız eğitimin zorluğuna göre flüt çok basit. Flüt yerine kontrpuan gibi dersler olsa armoniyi destekler” (Ö15) açıklamasında bulunmuştur (Şekil 2).

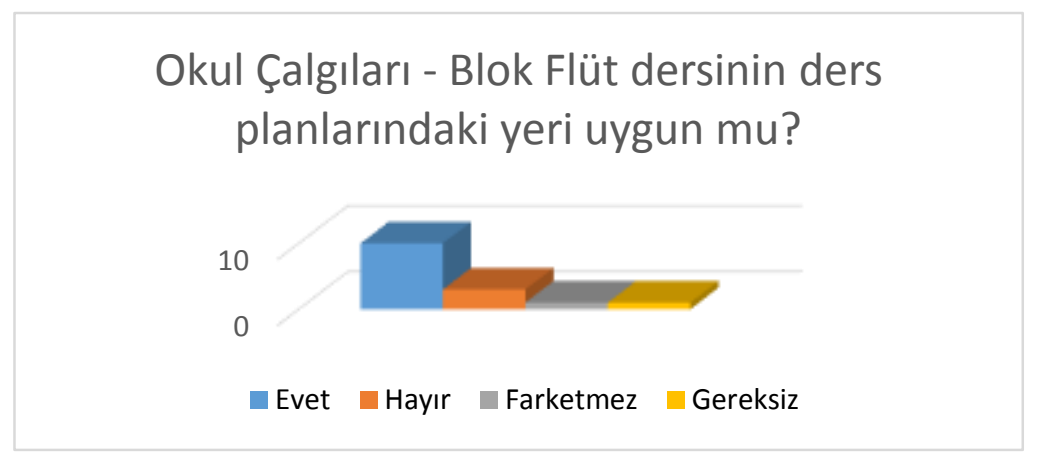

Şekil 2. Okul Çalgıları - Blok Flüt dersinin ders planındaki yerini uygun bulma durumları

Öğrenciler Okul Çalgıları - Blok Flüt dersinin 1. yıl olmasının “okula uyum sağlamak, ileriki yıllarda ders programlarındaki yoğunluk, basit ve eğlenceli olması, her dönem farklı okul çalgısı öğrenecek olmaları ve dersin öğrencileri müzik öğretmeni adayı olarak hissettirmesi" açısından uygun olduğunu belirtmişlerdir. Bunun aksine uygun olduğunu düşünmeyen ve öğretmenlik uygulaması dersinden dolayı son yıl olması gerektiğini düşünen iki öğrenci, aynı gerekçeden dolayı 3. yıl olması gerektiğini düşünen bir öğrenci bulunmaktadır.

Öğrencilere “Genel müzik eğitiminde yer alan blok flüt eğitimi hakkındaki görüşleriniz nelerdir?” diye sorulmuştur. Öğrenciler blok flütü, küçük yaştaki öğrencilere 
müziği sevdirebilecek, ucuz ve çalması kolay olduğu için müzik derslerinde kullanılabilecek avantajlı bir çalgı olarak görmektedirler. Ayrıca müzik derslerinde yapılacak uygulamalar ile öğrencilerin entonasyon açısından gelişim gösterirken çoksesli müziğe de yatkınlıklarının artacağını düşünmektedirler. Bunun yanı sıra okullarda genel müzik eğitimi içerisinde uygulanan blok flüt eğitiminin "yetersiz olduğunu, öğretilmede farklı yöntem ve tekniklerin kullanılması gerektiğini” düşünen bir öğrenci bulunmaktadır.

\section{Öğrencilerin Okul Çalgıları - Blok Flüt Dersinden Beklentileri}

Öğrencilerin Okul Çalgıları - Blok Flüt dersinden beklentilerini belirlemek adına müzikal beklentileri, öğretmenlik mesleği açısından beklentileri, Türk Müziği açısından beklentileri ve genel beklentileri sorulmuştur.

Öğrencilerin Okul Çalgıları - Blok Flüt dersinden müzikal açıdan beklentileri. Öğrenciler, Okul Çalgıları - Blok Flüt dersine yönelik müzikal beklentilerini şöyle belirtmişlerdir: "Nota okuma ve nefes kontrolü açısından faydalı olabilir. İleride üflemeli herhangi bir çalgıya ilgim olursa yabancılığımı azaltabilir” (Ö1), "el pratikliği ve entonasyon açısından kendimi daha fazla ilerletmek" (Ö5), “iki el koordinasyonumu geliştirmenin yanı sıra aralık bilgimi ve sesleri tanıma açısından gelişmek" (Ö6), "diyaframımı geliştirerek nefes kontrolünü sağlamak” (Ö10), “bu çalgıya karşı farklı bakış açısında olmak” (Ö12), “deşifremi geliştirmek ve pratikliğimin artması" (Ö13). Bu ders ile blok flüt çalma becerilerini, aralık bilgilerini ve sesleri tanıma becerileri ile nefes kontrolünü sağlamayı bekleyen öğrencilerin yanı sıra bu dersten müzikal açıdan beklentisi olmayan beş öğrenci, bu dersin müzikal gelişim açısından katkısı olmayacağını düşünen dört öğrenci vardır.

\section{Öğrencilerin Okul Çalgıları - Blok Flüt dersinden öğretmenlik mesleği açısından}

beklentileri. Öğrencilerin Okul Çalgıları - Blok Flüt dersinden müzik öğretmenliği mesleği açısından beklentileri “iyi çalma” ve "iyi öğretme” olarak kodlanmıştır. 
İyi çalma. Öğrenciler "her müzik öğretmeninin blok flütü çok iyi çalması gerektiği”" (Ö4), “iyi çalıyor olmak müzik öğretmenliği kariyerinde kolaylıklar sağlayacağı” (Ö6) için blok flütü iyi çalabilecekleri bir eğitim alma beklentisindeler.

İyi öğretme. Ayrıca öğrencilerin “iyi öğretme” açısından beklentileri şöyledir: “Öğrencilere öğretecek düzeyde hâkim hale gelebilmek” (Ö1), "sınıfta öğrenciler aras1 uyumu, birlikteliği sağlamak, öğrencilerin becerilerini kontrol etmek gibi konuları kavrayıp ileride meslek hayatımızda uygulamak üzere kendimizi geliştirebileceğimiz bir ders beklentisindeyim” (Ö8), “çalgı öğretiminde kullanılan metotlar, farklı yöntem ve yaklaşımları öğrenmeyi bekliyorum. Nasıl daha iyi çalabilirim ve nasıl daha iyi öğretirim? Öğrenmek istediklerim bunlar” (Ö9), “yaşı küçük olan çocuklarla yapılacak derslerde eğlenceli metotlar ve melodiler ile onların derse odaklanmasını ve daha keyifli ders işlemeyi öğrenmeyi bekliyorum"(Ö12), "blok flüt hâkimiyetimin yanı sıra çocuklara nasıl öğretebileceğimi öğrenmek istiyorum” (Ö13).

\section{Öğrencilerin Okul Çalgıları - Blok Flüt dersinden Türk Müziği açıdan}

beklentileri. Türkiye'deki blok flüt metotları incelendiğinde çoğunluğunun içeriğinde türkülere yer verildiği görülmektedir. Bu durum eğitimde ulusaldan evrensele anlayışını desteklemekte, hayatımızda olan müziklerin de müzik eğitimine katılmasıyla bu derse ilgi arttırılmaktadir.

Öğrencilere Okul Çalgıları - Blok Flüt dersinden Türk Müziği açısından beklentileri sorulduğunda yedi öğrenci bu konuda bir beklentisi olmadığını belirtmiştir. Bunun yanı sıra öğrencilerin “Türk müziğindeki eserleri çocuklara blok flüt ile öğretip sevdirebilmek” (Ö5), “derslerde Türk Müziğine daha çok yer verilerek basit makamsal ezgileri çalabilir duruma gelmek" (Ö9), komalı seslerin çalışılarak makamsal ezgilerin seslendirilmesi gibi beklentileri bulunmaktadır. 
Öğrencilerin genel olarak Okul Çalgıları - Blok Flüt dersinden beklentileri, çalgıyı öğrencilere öğretebilecek düzeye gelebilmek yönündedir. Öğrenciler genel müzik eğitiminde bu çalgıya sıkça yer verildiği ve iyi birer öğretmen olabilmek için bu çalgıyı çalma becerilerinin yüksek olması gerektiği bilincindedirler. Çalgıyı doğru çalmak, el pratikliği ve entonasyon açısından gelişmek, kolay deşifre yapabilmek öğrencilerin beklentileri arasındadir.

\section{Tartışma ve Sonuç}

Yapılan araştırma ile öğrencilerin genel müzik eğitimlerinde blok flüt çalmayı öğrenmiş olmalarına rağmen Okul Çalgıları - Blok Flüt dersini gerekli buldukları sonucuna varılmıştır.

Ayrıca öğrencilerin çoğu Okul Çalgıları - Blok Flüt dersinin müzik öğretmenliği programında 1. yılda yer alıyor olmasının uygun olduğunu düşünmektedirler. Uludağ Üniversitesi Müzik Eğitimi Ana Bilim Dalı ders planlarında öğrencilerin her dönem farklı bir okul çalgısı (blok flüt, gitar, mandolin, Orff, vurmalı çalgılar) çalışması sağlanmaktadır. 2016-2017 Eğitim - Öğretim yılında Okul Çalgıları dersleri I - V. yarıyıllar arasında okutulmaktadır. I. ve II. yarıyıllarda Okul Çalgıları - Blok Flüt ve Okul Çalgıları - Gitar, III. ve IV. yarıyıllarda Okul Çalgıları - Gitar, Okul Çalgıları - Mandolin, Okul Çalgıları - Orff Çalgıları ve Okul Çalgıları - Vurmalı Çalgılar, V. yarıyılda Okul Çalgıları - Gitar, Okul Çalgıları - Orff Çalgıları ve Okul Çalgıları - Vurmalı Çalgılar dersleri yer almaktadır. Araştırmaya katılan üç öğrenci Okul Çalgıları - Blok Flüt dersinin öğretmenlik uygulaması dersine daha fazla katkıda bulunacağından dolayı V.- VI. yarıyıllar ya da VII. - VIII. yarıyıllarda yer almasının daha iyi olacağı görüşündedir.

Öğrenciler, blok flüt çalgısının alımı ucuz ve öğrenilmesi diğer çalgılara göre daha kolay olduğundan genel müzik eğitimi için uygun bir çalg1 olduğunu, ayrıca bu çalg1 ile 
çoksesli müziğe yatkınlığın arttırılabileceğini düşünmektedirler. Benzer sonuçlar blok flüt ile ilgili yapılmış farklı çalışmalarda da elde edilmiştir (Önal ve Aydoğan, 2012).

Öğrencilerin Okul Çalgıları - Blok Flüt dersinden Türk Müziği açısından beklentileri “eserlerin sözlerine ve melodilerine kulak aşinalığı olması, yöresel ezgileri blok flüt ile seslendirmek, marşların çalınması, ders içeriklerinde çocukların severek seslendireceği Türk Müziği ezgilerine yer verilmesi, derslerde Türk Müziğine daha çok yer verilmesi, basit makamsal ezgilerin seslendirilmesi, farklı dudak ve parmak pozisyonu ile komalı seslerin çıkartılmasının öğrenilmesi” olarak özetlenebilir. Birer (2016) yaptığı araştırmanın sonucunda öğrencilerin büyük bir çoğunluğunun dersten beklentisinin "blok flütü en iyi şekilde çalabilmek ve öğrencilerime öğretebilmek" olarak belirlemiştir. Yapılan araştırma ile müzik öğretmeni adaylarının blok flüt dersinden en büyük beklentilerinin iyi çalabilmek olduğu kadar iyi öğretebilecek seviyede olabilmek olduğu pekiştirilmiştir. Öğrencilerin genel olarak Okul Çalgıları - Blok Flüt dersinden beklentisi çalgıyı öğretebilecek seviyede iyi çalmak, deşifrelerini kuvvetlendirmek, becerilerini arttırmaktır.

Okul Çalgıları - Blok Flüt dersine yönelik öğrencilerin önerileri sorulduğunda ders işlenişinden oldukça memnun olduğunu belirten 10 öğrenci bulunmaktadır. Bunun yanı sıra öğrencilerin derse yönelik önerileri şöyledir:

- Ders araları fazlalaştırılmalı. Dersin yoğunluğu azaltılmalı (Ö1).

- Derste ritim çalgıları ve eşlikler kullanılmalı (Ö2).

- Nefes egzersizleri çalıştırılmalı (Ö8).

- Dersler drama ile birleştirilerek çeşitli kompozisyonlar oluşturulabilir (Ö13).

- Beste çalışmaları yapılabilir (Ö13).

- Derste güncel melodilere de yer verilebilir (Ö14). 
Öğrencilerin önerilerine ek olarak araştırma sonucunda elde edilen veriler doğrultusunda,

- Dönem başında öğrencilerin beklentileri belirlenerek ders planlarının bu doğrultuda hazırlanmas1,

- Blok flütün genel müzik eğitiminde nasıl öğretileceğine yönelik uygulamaların yapilmasi,

- Okul Çalgıları - Blok Flüt derslerinde Türk Müziği ve güncel müziklere de yer verilmesi,

- Dağarcık geliştirmek ve öğrencilerin metotları tanımasını sağlamak adına derste farklı metotların kullanılması,

- Ders içeriğine blok flüt için bestelenmiş uluslararası bestecilerin eserlerinin eklenmesi,

- Dönem sonunda öğrenciler ile blok flüt dinletisinin gerçekleştirilmesi önerilmektedir.

\section{Makalenin Bilimdeki Konumu (Yeri)}

Güzel Sanatlar Eğitimi Bölümü, Müzik Eğitimi Ana Bilim Dalı

\section{Makalenin Bilimdeki Özgünlüğü}

Makalede Müzik Eğitimi Ana Bilim dalı 1. Sınıf öğrencilerinin Okul Çalgıları - Blok flüt dersine yönelik beklentileri belirlenmiş, böylece çağdaş öğretmen yetiştirme amaciyla bu beklentilere yönelik ders içeriklerinin gözden geçirilmesi önerilmiştir. Bu araştırma ile farklı açılardan tartışma konusu olan genel müzik eğitiminde blok flüt kullanımının müzik öğretmeni adayı olan öğrenciler tarafından nasıl değerlendirildiği ortaya konulmuştur.

\section{Kaynakça}

Abant İzzet Baysal Üniversitesi Derece Programları. (2016).

http://bologna.ibu.edu.tr/CourseDetail.aspx?lang=trTR\&opID=340\&pmID=3871\&mid= 179170\&DersID=1942\&dersKodu=112001292006 adresinden alınmıştır. 
Appleton-Knapp, S.L. ve Krentler, K.A. (2006). Measuring Student Expectation and Their Effects on Satisfaction: The Importance of Managing Student Expectation. Journal of Marketing Education. 28(3), 254-264. http://jmd.sagepub.com/content/28/3/254.short adresinden alınmıştır.

Arıcı, İ. (2007). Sihirli Flüt Blok flüt Metodu. İstanbul: Porte MEM.

Aydoğan, S. (2011). Renklerle Blokflüt Öğreniyorum. Ankara: Arkadaş Yayınevi.

Aydoğan, S. ve İlik, A.A. (2016). Blokflüt ile Müzik Ĕ̌gitimi (34. Baskl). Ankara: Arkadaş Yayınevi.

Birer, A.R.H. (2016). Okul Çalgıları I ve Okul Çalgıları II Derslerinin Öğrenci Beklentileri ve Beklentilerin Karşılanma Düzeyi Açısından İncelenmesi (Ömer Halisdemir Üniversitesi Örneği). TURAN-SAM Uluslararası Bilimsel Hakemli Dergisi. 8(32), 251-254. http://www.turansam.org/TURAN-SAM_32.pdf adresinden alınmıştır.

Bozkaya, İ. (2001). Okul Ortamında Müzik. Bursa: F. Özsan Matbaacıl1k

Brinkworth, R., McCann, B., Matthews, C. ve Nordström, K. (2009). First Year Expectations and Experiences: Student and Teacher Perspectives. Higher Education. 58(2), 157-173. http://link.springer.com/article/10.1007/s10734-008-9188-3 adresinden alınmıştır.

Büyüköztürk, Ş., Çakmak, E.K., Akgün, Ö.E., Karadeniz, Ş. ve Demirel, F. (2014). Bilimsel Araştırma Yöntemleri (18. Baskı).Ankara: Pegem Afademi Yayıncılık.

Caroll, B. (1968). The Recorder in Music Education. Australian Journal of Music Education, $3,29-31$. https://search.informit.com.au/documentSummary;dn=817030877258181;res=IELHSS adresinden alınmıştır. 
Chaseling, M. ve Boyd, W.E. (2014). The decline and Revival of Music Education in New South Wales School, 1920-1956. Australian Journal of Music Education, 2, 46-61. http://files.eric.ed.gov/fulltext/EJ1061980.pdf adresinden alınmıştır.

Crips, G., Palmer, E., Turnbull, D., Nettelbeck, T., Ward, L., LeCouteur, A., Sarris, A., Strelan, P., ve Schneider, L. (2009). First Year Student Expectations: Results from a University-Wide Student Survey. Journal of University Teaching \&Learning Practice, 6 (1), 13-26. http://eric.ed.gov/?id=EJ867293 adresinden alınmıştır.

Çalım, N. (2013). Blokflüt Öğreniyorum Blokflüt Metodu. İstanbul: Zafer Matbaası.

Çelikkaya, T. (2011). Sosyal Bilgiler Öğretmen Adaylarının Öğretmenlik Uygulaması Dersinden Beklentileri ve Bu Beklentilerin Karşılanma Düzeyleri. Uluslararası Sosyal Bilimler Eğitimi Dergisi, $\quad 1(2), \quad$ 155-172. http://www.limnofish.org/issej/issue/26445/278902 adresinden alınmıştır.

Çepni, S. (2014). Araştırma ve Proje Çalışmalarına Giriş (7. Baskı). Trabzon: Celepler Matbaac1lik.

Değerli, T. (n.d.). Blok Flüt Metodu. İzmir: Öz Atak Matbaacılık ve Reklam Hizmetleri

Dokuz Eylül Üniversitesi Derece Programları. (2016). http://debis.deu.edu.tr/derskatalog//2016-2017/tr/tr_1109_1109_1839.html adresinden alınmıştır.

Egüz, S. (n.d.). Türkü ve Oyun Havalarımızdan Bir Demet. Ankara: Doğuş Ltd. Sti. Matbaası. Kıvrak, Y. (Ekim, 2003). Müzik Eğitimi Çalgılarımız "İlk 40 Yıla Damgasını Vuran Mandolin, Son 30 yıla Damgasını Vuran Blokfülüt ve Son Yıllarda Müzik Eğitimimizde Zorlamasız Olarak Kendine Kendiliğinden Bir Yer Bulan Klasik Gitar. Sözlü bildiri, Cumhuriyetimizin 80. Yılında Müzik Sempozyumu. İnönü Üniversitesi Malatya. http://www.muzikegitimcileri.net/bilimsel/bildiri/Y-Kivrak_2.html adresinden alınmıştır. 
Karahasan, T.H. (n.d.). Blokflüt Metodu. Trabzon: Esen Ofset Matbaacılik.

Kocabaş, A. (1995). İşbirlikli ögrrenmenin blokflüt ögrretimi ve ögrenme stratejileri üzerindeki etkileri. Yayımlanmamış Doktora Tezi, Sosyal Bilimler Enstitüsü, Dokuz Eylül Üniversitesi, İzmir.

Marmara Üniversitesi Programlar Hakkında Bilgi. (2016).

http://lip.marmara.edu.tr/course.aspx ?zs=1\&mod=1\&kultur=trTR\&program=13\&did=7 45\&mid=2492\&pmid=13\&mufredatTurId=932001\&organizasyonId=15 adresinden alınmıştır.

Müzik Öğretmenliği Lisans Programı. (2016). http://www.yok.gov.tr/documents/10279/49665/muzik_ogretmenligi.pdf/831bd1ffe3cb4d2e-bbf8-cf80f6d0e209 adresinden alınmıştır.

Öcal, A.O. (2014). Illkögrretim ikinci kademe müzik dersi öğretim programlarında uygulanan blok flüt eğitimine ilişkin öğretmen görüşleri (Ankara ili örneği). Yayımlanmamış Yüksek Lisans Tezi, Eğitim Bilimleri Enstitüsü, Gazi Üniversitesi, Ankara.

Önal, A.A. ve Aydoğan, S. (2012). Bir Sınıf Çalgısı Olarak Blokflütün İlköğretim Müzik Dersi Öğretim Programını Gerçekleştirebilmedeki Yeterliliği. Süleyman Demirel Üniversitesi Güzel Sanatlar Fakültesi Hakemli Dergisi, 10, 57-75.

Öztürk, F.G. (2004). G.Ü. Gazi Eğitim Fakültesi Güzel Sanatlar Eğitimi Bölümü Müzik Öğretmenliği Anabilim Dalında Çalgısı "Şan” Olan Öğrencilerin Ses Eğitiminden Beklentileri. Gazi Eğitim Fakültesi Dergisi, 24(1), 177-189. http://gefad.gazi.edu.tr/article/view/5000078813 adresinden alınmıştır.

Redish, E.F., Saul, J.M. ve Steinberg, R.N. (1998). Student Expectations in Introductory Physics. American Journal of Physics, 66(3), 212-224. 
http://scitation.aip.org/content/aapt/journal/ajp/66/3/10.1119/1.18847

adresinden alınmıştır.

Say, A. (2010). Müzik Ansiklopedisi (1. Cilt). Ankara: Müzik Ansiklopedisi Yayınları.

Turan, D. (2010). Blokflüt Çalmaya Başlıyorum. İstanbul: Nota Yayımcılık.

Uçaner, B.ve Şentürk, N. (2013). Müzik Eğitimi Anabilim Dalı Öğrencilerinin “Türk Müzik Tarihi” Dersinin İşlenişine Yönelik Görüşleri. International Journal of Human Sciences, 10(1), 730-749. http://www.acarindex.com/dosyalar/makale/acarindex1423873737.pdf adresinden alınmıştır.

Ural, A. ve Kılıç, İ. (2013). Bilimsel Araştırma Süreci ve SPSS ile Veri Analizi (4. Baskl). Ankara: Detay Yayıncilık.

Ünal, S. (1987). Blokfülüt Çallyorum 1. Ankara: Evrensel Müzikevi.

Yıldırım, S.ve Akkuş, B. (1987). Halk Ezgileriyle Blokfülüt Metodu Okul Türkü Dă̆arcı̆̆ı 1. Ankara: Ezgi Yayıncılık.

Yıldırım, S. ve Akkuş, B. (1987). Halk Ezgileriyle Blokfülüt Metodu Okul Türkü Dă̆arcı̆̆ı 2. Ankara: Ezgi Yayıncılık. 